\title{
Artikel
}

\section{Klimaatverandering en strafrecht: een verkenning}

\author{
Mr. S.J. (Sjoerd) Lopik en mr. S.H. (Seppe) Stax*
}

\section{Inleiding}

Klimaatverandering is niet meer weg te denken uit het publieke debat. In het afgelopen jaar stond het onderwerp vaak op de politieke agenda, werd Greta Thunberg uitgeroepen tot Time Person of the Year en was het Urgenda-arrest een van de meest besproken gerechtelijke uitspraken van het jaar. Binnen het strafrecht wordt nog weinig aandacht aan klimaatverandering besteed, maar dat zal op korte termijn veranderen. Dit artikel bevat een verkenning van de strafrechtelijke aansprakelijkheid van partijen die bijdragen aan klimaatverandering en de strafrechtelijke handhaving van klimaatwetgeving.

De klimaatverandering die op dit moment zoveel belangstelling krijgt, wordt veroorzaakt door de uitstoot van broeikasgassen, waarvan koolstofdioxide $\left(\mathrm{CO}_{2}\right)$ en methaan de bekendste zijn. ${ }^{1}$ De groeiende deken van broeikasgassen rondom de aarde zorgt ervoor dat minder warmte naar het heelal ontsnapt. Hierdoor warmt de aarde op. Als de uitstoot van broeikasgassen niet spoedig afneemt, dan brengt deze opwarming desastreuze gevolgen teweeg. ${ }^{2}$

* $\quad$ Beide auteurs zijn advocaat bij Allen \& Overy te Amsterdam. Dit artikel is afgerond op 19 mei 2020. Met ontwikkelingen nadien is geen rekening gehouden.

1. De relevante opsomming van broeikasgassen voor het Europees en Nederlands recht is te vinden in Bijlage 1 van Verordening (EU) 525/2013.

2. Voor een overzicht van deze gevolgen, zie bijvoorbeeld D. WallaceWells, The Uninhabitable Earth, London: Penguin Books Ltd, 2019.
Het Urgenda-arrest van de Hoge Raad dwingt de overheid om de emissies van broeikasgassen eind 2020 te hebben teruggebracht tot ten minste $25 \%$ ten opzichte van 1990. ${ }^{3}$ De Europese Unie stelt zich, mede op grond van de Overeenkomst van Parijs, als doelstelling om in 2050 klimaatneutraal te zijn. ${ }^{4}$ De Europese Commissie presenteerde in dit verband de eerste Europese Klimaatwet op 5 maart 2020. Deze wet beoogt deze doelstelling juridisch bindend te maken voor de lidstaten. ${ }^{5}$ Nederland had deze doelstelling al eerder vastgelegd in de Klimaatwet. Deze wet beoogt dat broeikasgasemissies in 2050 met 95\% zijn gereduceerd ten opzichte van $1990 .{ }^{6}$

Volgens Spier, voormalig advocaat-generaal bij de Hoge Raad en thans hoogleraar Law and Global Challenges aan de Universiteit van Amsterdam, moet haast ieder rechtsgebied worden benut om die klimaatdoelen te halen:

'We should tackle climate change from as many angles as possible. If the law is going to play a role, it must be a joint effort of lawyers in many fields, such as international law, human rights, environmental law, private law and criminal law. ${ }^{7}$

Nederland heeft intussen nog onvoldoende daadwerkelijke klimaatmaatregelen genomen. 'Ons klimaatbeleid is

3. HR 20 december 2019, ECLI:NL:HR:2019:2006.

4. Commissiedocument 773 van 2018. Klimaatneutraliteit betekent dat er een evenwicht moet zijn tussen de $\mathrm{CO}_{2}$-uitstoot en de opname van $\mathrm{CO}_{2}$ uit de atmosfeer in natuurlijke koolstofputten (natural sinks), zoals bomen.

5. Commissiedocument 80 van 2020

6. Art. 2 lid 1 Klimaatwet.

7. J. Spier, 'High noon: prevention of climate change as the primary goal of liability?', in: M. Faure \& M. Peeters, Climate Change Liability: New Horizons in Environmental and Energy Law series, Northampton: Edward Elgar Publishing 2011, p. 50. 
tot nu toe vooral de aankondiging van maatregelen', aldus politiek columnist Tom-Jan Meeus. ${ }^{8}$ Het Planbureau voor de Leefomgeving becijferde eind 2019 dat nog veel moet gebeuren om de klimaatdoelen te halen. ${ }^{9}$ Door het significante effect van de coronacrisis op de $\mathrm{CO}_{2}-$ uitstoot, zal de Staat het gebod uit het Urgenda-arrest in 2020 naar verwachting naleven. De Staat heeft echter vooralsnog onvoldoende maatregelen genomen om de $\mathrm{CO}_{2}$-uitstoot structureel terug te brengen. ${ }^{10}$ De overheid zal veel nieuw klimaatbeleid moeten ontwikkelen en meer moeten handhaven ten aanzien van het huidige en toekomstige klimaatbeleid. Het is daarom zeer waarschijnlijk dat klimaatverandering ook in het strafrecht een belangrijkere rol gaat spelen.

Dit artikel bevat een verkenning van de strafrechtelijke aansprakelijkheid van partijen die bijdragen aan klimaatverandering en de strafrechtelijke handhaving van klimaatwetgeving. In deze bijdrage bespreken wij allereerst waarom het veroorzaken van klimaatverandering als zodanig niet strafbaar is. Vervolgens lichten wij toe dat wel strafrechtelijke onderzoeken plaatsvinden naar het onjuist of onvolledig informeren van investeerders over klimaatverandering. Wij bespreken daarna klimaatwetgeving waarvan overtredingen via de Wet op de economische delicten (WED) strafbaar zijn gesteld. Voorbeelden hiervan zijn regels met betrekking tot het Europese emissiehandelssysteem en de maximumuitstoot van auto's. In de laatste paragraaf staan wij stil bij mogelijke toekomstige klimaatwetgeving en de rol van het strafrecht bij de handhaving van dergelijke regelgeving.

Dit artikel ziet alleen op het nationale strafrecht. Initiatieven om het internationaal strafrecht een rol te laten spelen bij het tegengaan van klimaatverandering worden hier niet besproken. ${ }^{11} \mathrm{Wij}$ bespreken daarnaast alleen aansprakelijkheid van private partijen, en niet van overheidsorganen.

\section{Strafbaarheid van veroorzaken klimaatverandering als zodanig}

Het veroorzaken van klimaatverandering levert als zodanig geen strafbaar feit op naar Nederlands recht. ${ }^{12}$ Wereldwijd roepen verschillende partijen echter op tot het initiëren van strafprocessen voor het veroorzaken van klimaatverandering. ${ }^{13} \mathrm{Bij}$ dergelijke oproepen wil men uitstoters van broeikasgassen strafrechtelijk aansprakelijk stellen voor de gevolgen van die uitstoot. De Amerikaanse senator Bernie Sanders lijkt bijvoorbeeld te pleiten voor strafrechtelijke vervolging van veroorzakers van klimaatverandering door vernieling, in Nederland strafbaar gesteld in artikel $350 \mathrm{Sr} .{ }^{14}$ In de Amerikaanse juridische literatuur wordt het veroorzaken van klimaatverandering geassocieerd met mishandeling, in Nederland strafbaar gesteld in artikel $300 \mathrm{Sr} .{ }^{15}$ In het verlengde hiervan zou men ook kunnen denken aan vervolging ter zake van de strafbaarstelling van het wederrechtelijk in de lucht brengen van een stof waarvan gevaar voor de openbare gezondheid te duchten is, in de zin van artikel 173a Sr. Dit soort algemene oproepen tot strafvervolging kunnen onder strafrechtjuristen echter op weinig steun rekenen. ${ }^{16} \mathrm{Wij}$ noemen hier kort de belangrijkste redenen, en richten ons daarbij op de drie voornoemde delicten.

Een veroordeling voor het veroorzaken van klimaatverandering als zodanig is moeilijk voorstelbaar, omdat het uitstoten van broeikasgassen op dit moment (nog) nagenoeg inherent is aan het leven in een geïndustrialiseerde samenleving. Een mogelijkheid tot veroordeling voor het veroorzaken van klimaatverandering zou bijna iedere persoon binnen die samenlevingen tot crimineel maken, zo wordt ook in de Amerikaanse juridische literatuur betoogd. ${ }^{17}$

12. Geen enkele jurisdictie kent zo'n strafbaarstelling, zie bijvoorbeeld R. Kramer, 'Climate Change: A State-corporate Crime Perspective', in: T. Spapens, R. White \& M. Kluin (red.), Environmental Crime and its Victims: Perspectives within Green Criminology, Farnham: Ashgate, 2014.

13. R. White, 'Climate change, ecocide and the crimes of the powerful', in: G. Barak (red.), The Routledge International Handbook of the Crimes of the Powerful, Abingdon: Taylor \& Francis Ltd, p. 98-101.

14. C. Bannister, 'Bernie Sanders Hypes His Green New Deal: Fossil Fuel Executives Should be Criminally Prosecuted', CNS News 23 augustus 2019, www.cnsnews.com/blog/craig-bannister/bernie-sanders-hypeshis-green-new-deal-fossil-fuel-executives-should-be.

15. Zie bijvoorbeeld M. Byrne, 'Climate Crime: Can Responsibility for Climate Change Damage be Criminalised?', Carbon \& Climate Law Review 4(3), 2010, p. 279

16. Zie bijvoorbeeld R. White, 'Climate change, ecocide and the crimes of the powerful', in: G. Barak (red.), The Routledge International Handbook of the Crimes of the Powerful, Abingdon: Taylor \& Francis Ltd, p. 101 en M. Hall, 'Criminal law and climate change', in: M. Faure (red.), Elgar Encyclopedia of Environmental Law, Cheltenham: Edward Elgar Publishing, 2016, p. 103.

17. M. Byrne, 'Climate Crime: Can Responsibility for Climate Change Damage be Criminalised?', Carbon \& Climate Law Review 4(3), 2010, 
Men zou dan kunnen stellen dat louter partijen die veel broeikasgassen uitstoten moeten worden vervolgd, zoals in Sanders' oproep tot strafvervolging van 'fossil fuel executives'. ${ }^{18}$ Ook die stelling vindt geen steun in het Nederlands recht, omdat het vereiste causaliteitsverband ontbreekt. Voor een veroordeling op grond van artikel $350 \mathrm{Sr}$ of artikel $300 \mathrm{Sr}$ is een causaal verband vereist. Ook artikel 173a Sr lijkt een causaliteitsvereiste te kennen. ${ }^{19}$ Daarbij zou sprake moeten zijn van een verband tussen de oorzaak, te weten de uitstoot van broeikasgassen door een bepaalde partij, en het gevolg, bijvoorbeeld schade of letsel door natuurverschijnselen die het gevolg zijn van klimaatverandering. Dit causaal verband valt naar geldend Nederlands strafrecht niet te construeren. De Nederlandse strafrechter hanteert voor causaliteitsvraagstukken de leer van de redelijke toerekening, waarbij de theorie van conditio sine qua non de ondergrens vormt. Deze theorie houdt in dat het gedrag redelijkerwijs een noodzakelijke voorwaarde voor het gevolg moet zijn geweest. ${ }^{20}$ Voor een veroordeling voor het veroorzaken van klimaatverandering betekent dit dat ten minste moet worden aangetoond dat bepaalde schade niet zou zijn ontstaan als een bepaalde partij geen broeikasgassen had uitgestoten. Allereerst is het twijfelachtig of overtuigend (in de zin van artikel $338 \mathrm{~Sv}$ ) kan worden bewezen dat een enkel natuurverschijnsel is veroorzaakt door klimaatverandering. Als dat al bewijsbaar zou zijn, dan lijkt het vervolgens onmogelijk om die klimaatverandering (mede) toe te rekenen aan de uitstoot door één bepaalde partij.

Een vervolging van een partij omdat deze veel broeikasgassen uitstoot zou waarschijnlijk ook niet slagen, omdat dit op gespannen voet zou staan met het legaliteitsbeginsel. ${ }^{21}$ In de civielrechtelijke Urgenda-jurisprudentie konden rechters open normen extensief interpreteren. Het strafrecht biedt minder mogelijkheden voor extensieve interpretatie. De strafwet moet voldoende concreet duidelijk maken welke gedragingen strafbaar zijn en moet de verdachte in staat stellen zijn gedrag

p. 279. Hierbij moet worden opgemerkt dat het strafrecht geen equivalent kent van het civielrechtelijke leerstuk kansschade.

18. C. Bannister, 'Bernie Sanders Hypes His Green New Deal: Fossil Fuel Executives Should be Criminally Prosecuted', CNS News 23 augustus 2019, www.cnsnews.com/blog/craig-bannister/bernie-sanders-hypeshis-green-new-deal-fossil-fuel-executives-should-be.

19. Hof 's-Hertogenbosch 27 maart 2007, ECLI:NL:GHSHE:2007:BB5050. Zie ook A. De Lange, 'Commentaar op artikel 173a Sr', in: Tekst \& Commentaar Strafrecht, via Kluwer Navigator, 10 augustus 2004. Daarbij moet worden opgemerkt dat De Lange het bestaan van dit causaliteitsvereiste lijkt te concluderen op basis van enkel de voornoemde uitspraak van het hof 's-Hertogenbosch. De vraag naar het causaliteitsvereiste van art. 173a Sr lijkt dus nog niet uitgekristalliseerd in de jurisprudentie.

20. HR 12 september 1978, ECLI:NL:HR:1978:AC2616. Alleen in zeer uitzonderlijke gevallen kan een gevolg worden toegerekend zonder dat het vereiste van condicio sine qua non is bewezen. Het gaat dan met name om omissiedelicten, en gevallen waarin onduidelijkheid bestaat doordat er meerdere mogelijk aanwijsbare oorzaken van het ingetreden gevolg zijn.

21. Art. 1 lid 1 Sr, art. 7 EVRM en art. 49 Handvest van de grondrechten van de Europese Unie. daarop af te stemmen. ${ }^{22}$ Aan dit vereiste wordt niet voldaan in geval van strafvervolging voor het uitstoten van broeikasgassen. De wetgever heeft het immers blijkbaar toelaatbaar geacht dat broeikasgassen worden uitgestoten. Dit blijkt uit het feit dat productieprocessen zijn toegestaan en gereguleerd waarvan broeikasgassen onvermijdelijke bijproducten zijn, zoals de productieprocessen voor melk en vlees. Als een producent normconform een gereguleerd product fabriceert, dan is het, op grond van het legaliteitsbeginsel, moeilijk denkbaar dat hij de facto voor het produceren van dat product zou worden gestraft. ${ }^{23}$ In het verlengde hiervan ligt dat een vervolging voor overtreding van artikel $173 \mathrm{a} \mathrm{Sr}$ niet zal slagen, omdat dit artikel een wederrechtelijkheidsvereiste kent en het uitstoten van broeikasgassen als zodanig niet wederrechtelijk is.

Tot slot kan een vervolging voor het uitstoten van veel broeikasgassen niet slagen, omdat dit zou leiden tot een verbod op bepaalde gereguleerde producten. Een verbod op een gereguleerd product moet niet via de rechter, maar via de wetgever worden afgedwongen. Dit volgt onder meer uit de beschikking ex artikel $12 \mathrm{~Sv}$ op een klacht tegen het niet-vervolgen van bepaalde tabaksfabrikanten. $^{24}$

\section{Informeren van beleggers over klimaatverandering}

Het veroorzaken van klimaatverandering is naar geldend (Nederlands) recht als zodanig dus niet strafbaar. Het is wel denkbaar dat een partij die broeikasgassen uitstoot, wordt aangesproken voor gedragingen rondom die uitstoot. Zo zijn Exxon Mobil en Shell in Amerika in verband gebracht met het onvoldoende of onjuist informeren van beleggers over klimaatverandering. Dit heeft voor beide partijen niet geleid tot een strafrechtelijke veroordeling, maar is in het kader van dit artikel wel interessant om te bespreken.

De attorney general van de staat New York deed strafrechtelijk onderzoek naar Exxon Mobil wegens een verdenking van het foutief inlichten van investeerders over de risico's van klimaatverandering. ${ }^{25}$ Dit onderzoek richtte zich op de vraag of publieke statements van

22. HR 28 mei 2002, ECLI:NL:HR:2002:AE1490. Zie in dit kader ook J.S Nan, Het Lex Certa-beginsel (diss. Tilburg University), pure.uvt.nl/ws/ portalfiles/portal/1376526/nan_lex_certa_28-09-2011.pdf, 2011.

23. J. de Hullu, Materieel strafrecht: over algemene leerstukken van strafrechtelijke aansprakelijkheid naar Nederlands recht, via Kluwer Navigator, 1 april 2018, par. II.3 en F.G.H. Kristen, 'Het materieelstrafrechtelijke legaliteitsbeginsel in het bijzonder strafrecht', in: F.G.H. Kristen e.a. (red.), Bijzonder strafrecht: Strafrechtelijke handhaving van sociaal-economisch en fiscaal recht in Nederland, Den Haag: Boom juridisch 2019, p. 399-448.

24. Hof Den Haag 6 december 2018, ECLI:NL:GHDHA:2018:3334.

25. J. Gillis \& C. Krauss, 'Exxon Mobil Investigated for Possible Climate Change Lies by New York Attorney General', The New York Times 5 november 2015, www.nytimes.com/2015/11/06/science/exxonmobil-under-investigation-in-new-york-over-climate-statements.html. 
Exxon Mobil strijdig waren met het wetenschappelijk onderzoek dat Exxon Mobil uitvoerde naar de gevolgen die klimaatverandering voor de onderneming zou hebben. Een rechtbank van de staat New York oordeelde in december 2019 dat er geen overtuigend bewijs was dat Exxon Mobil beleggers heeft misleid. ${ }^{26}$ Democratische Vertegenwoordigers in het Amerikaanse Huis van Afgevaardigden vroegen in 2016 om een soortgelijk onderzoek naar Shell. ${ }^{27}$ Aan dit verzoek lijkt (vooralsnog) geen gevolg te zijn gegeven.

Dit soort onderzoeken zijn ook in Nederland denkbaar. Het juist en volledig informeren van beleggers wordt in de Nederlandse rechtsorde onder meer bewaakt door de plicht om voorwetenschap openbaar te maken ${ }^{28}$ en het verbod op marktmanipulatie. ${ }^{29}$ Overtredingen van die normen worden in beginsel bestuursrechtelijk gehandhaafd, ${ }^{30}$ maar kunnen ook leiden tot strafrechtelijke vervolging. ${ }^{31}$ Daarnaast kent het commune strafrecht bepalingen die beogen te waarborgen dat juiste informatie wordt verstrekt, waaronder valsheid in geschrift ${ }^{32}$ en oplichting. ${ }^{33}$

Voor de volledigheid merken wij op dat het onjuist of onvolledig informeren van investeerders ook kan leiden tot civiele procedures. Wij zijn niet bekend met dergelijke zaken op klimaatgebied in Nederland, maar in Australië heeft wel zo'n zaak plaatsgevonden. Aandeelhouders van de Commonwealth Bank startten daar een procedure wegens gebrek aan disclosure door de bank over klimaatrisico's. Toen de bank haar beleid op dit gebied aanpaste, trokken de andeelhouders hun zaak in. ${ }^{34}$

26. J. Schwartz, 'New York Loses Climate Change Fraud Case Against Exxon Mobil', The New York Times 10 december 2019, www.nytimes.com/2019/12/10/climate/exxon-climate-lawsuit-newyork.html.

27. A. Adragna, 'House Democrats Ask DOJ to Probe Shell Climate Stance', Website of Congressman Ted Lieu 4 maart 2016, lieu.house.gov/ media-center/in-the-news/house-democrats-ask-doj-probe-shell-climate-stance.

28. Art. 17 Verordening (EU) 596/2014.

29. Art. 15 Verordening (EU) 596/2014

30. Zie bijvoorbeeld J.H. Crijns, 'Vervolging en berechting', in: F.G.H. Kristen e.a. (red.), Bijzonder strafrecht: Strafrechtelijke handhaving van sociaal-economisch en fiscaal recht in Nederland, Den Haag: Boom juridisch 2019, p. 626.

31. De strafbaarstelling van de overtreding uit deze twee bepalingen is geregeld in respectievelijk art. 1 onder $2^{\circ}$ en art. 1 onder $1^{\circ}$ WED.

32. Art. $225 \mathrm{Sr}$.

33. Art. $326 \mathrm{Sr}$

34. G. Hutchens, 'Commonwealth Bank shareholders drop suit over nondisclosure of climate risks', The Guardian 21 september 2017, www.theguardian.com/australia-news/2017/sep/21/commonwealthbank-shareholders-drop-suit-over-non-disclosure-of-climate-risks.

\section{Strafbaarheid van overtreding klimaatwetgeving}

Klimaatregelgeving krijgt met name vorm in het omgevingsrecht. In artikel 1 en artikel la WED wordt de overtreding van bepaalde klimaat-omgevingsrechtelijke normen als economisch delict, en dus als strafbaar feit, aangemerkt. In de volgende paragrafen geven wij een opsomming van enkele klimaatnormen waarvan overtreding in de WED strafbaar is gesteld. Vooralsnog vindt handhaving van deze normen met name plaats via het bestuursrecht. Wij zien in de praktijk echter dat bij herhaaldelijke overtreding van omgevingsrechtelijke normen, steeds vaker met de toepassing van het strafrecht wordt gedreigd of daadwerkelijk wordt overgegaan tot strafrechtelijke vervolging. Wij kunnen ons voorstellen dat deze trend niet anders zal zijn voor de handhaving van klimaatwetgeving.

Voordat wij klimaatwetgeving bespreken, bakenen wij dit begrip af. Wij ervaren zelf dat de discussie nogal eens vertroebelt doordat termen als 'duurzaamheid', 'stikstof', of 'circulaire economie' verkeerd worden gebruikt in relatie tot klimaatverandering. Bij 'klimaatwetgeving' in algemene zin gaat het om regelgeving gericht op broeikasgasreductie. Als eerste denkt men mogelijk aan de Nederlandse Klimaatwet, die wij in onze introductie al bespraken. De Klimaatwet kent echter geen concrete normstelling voor de burger, en kan daarom door een burger of onderneming niet worden overtreden. Hierdoor is de Klimaatwet niet relevant in het kader van het (klimaat)strafrecht. In het kader van dit hoofdstuk bespreken wij daarom wetgeving die gericht is op het reduceren van de uitstoot van broeikasgassen, een concrete normstelling voor de burger bevat én in de WED strafbaar is gesteld.

Achtereenvolgens komen aan de orde: het Europese emissiehandelssysteem, $\mathrm{CO}_{2}$-emissietesten voor voertuigen, de energiebesparingsplicht voor bedrijfspanden en de regels met betrekking tot methaanemissies en de uitfasering van gefluoreerde broeikasgassen. De eerste twee onderwerpen krijgen al ruimschoots aandacht binnen het strafrecht. De laatste twee krijgen dat (nog) niet.

\subsection{Klimaatwetgeving in de WED}

\subsubsection{Het Europese emissiehandelssysteem}

De meest in het oog springende regelgeving om de uitstoot van broeikasgassen te reduceren is het Europese emissiehandelssysteem dat is vastgelegd in de Europese Richtlijn Emissiehandel. ${ }^{35}$ De wetgeving rondom de emissiehandel is technisch van aard en wordt veelal als complex ervaren. ${ }^{36}$ Het Europese emissiehandelssys-

35. Richtlijn 2009/29/EG

36. Zie bijvoorbeeld P. Luttikhuis, 'Emissiehandel: niemand begrijpt hoe het werkt. Tien antwoorden', NRC Handelsblad 8 december 2019, nrc.nl/ 
teem startte op 1 januari 2005 en werkt volgens het principe van 'cap and trade' voor het uitstoten van broeikasgassen. Bedrijven die onder de Europese Richtlijn Emissiehandel vallen, worden aangeduid als deelnemers aan het Europese systeem voor emissiehandel. De deelnemers moeten een vergunning hebben voor het exploiteren van een broeikasgasinstallatie. Dit zijn installaties die een emissie van een broeikasgas van enige omvang in de lucht veroorzaken, zoals olieraffinaderijen en energieintensieve bedrijven uit de elektriciteitssector en chemische industrie. Als een bedrijf een broeikasgasinstallatie wil exploiteren, zijn daarvoor emissierechten nodig. Voor het uitstoten van (een equivalent van) een ton $\mathrm{CO}_{2}$ is één emissierecht vereist. Indien een bedrijf méér $\mathrm{CO} 2$ wil uitstoten, dan kan zij emissierechten kopen op de emissiehandelsmarkt. Deelnemers die emissierechten over hebben, kunnen deze verkopen. Op die manier ontstaat emissiehandel. Het Europese emissiehandelssysteem kent een emissieplafond: een maximumaantal emissierechten binnen de Europese Unie. Dit plafond gaat in elke handelsperiode omlaag, zodat de Europese industrie wordt gedwongen om iedere handelsperiode minder broeikasgassen uit te stoten. ${ }^{37}$

De Europese Richtlijn Emissiehandel is in Nederland geimplementeerd in hoofdstuk 16 Wet milieubeheer (Wm). De belangrijkste regels uit dat hoofdstuk zijn het verbod om zonder vergunning een broeikasgasinstallatie te exploiteren, het verbod meer uit te stoten dan waarvoor men emissierechten heeft, de verplichting tot het indienen van een emissieverslag bij de Nederlandse Emissieautoriteit, en de verplichting tot het naleven van een gevalideerd monitoringsplan dat specifieke gegevens over de installatie en emissies bevat.

Overtredingen van een aantal bepalingen uit hoofdstuk $16 \mathrm{Wm}$ zijn strafbaar gesteld in de WED. Het is onder meer strafbaar om zonder emissievergunning een broeikasgasinstallatie te exploiteren ${ }^{38}$ te handelen in strijd met de voorschriften onder een emissievergunning, ${ }^{39}$ te handelen in strijd met voorschriften uit een monitoringsplan ${ }^{40}$ en een dergelijk monitoringsplan doorlopend te actualiseren. ${ }^{41}$

Deelnemers aan het Europese emissiehandelssysteem dienen jaarlijks voor 1 mei minstens zoveel $\mathrm{CO}_{2}$-rechten bij de Nederlandse Emissieautoriteit in te leveren als zij aan broeikasgassen hebben uitgestoten. ${ }^{42}$ Het is niet direct via de WED strafbaar indien een onderneming onvoldoende emissierechten inlevert. ${ }^{43}$ De onderneming

nieuws/2019/12/08/10-vragen-over-emissiehandel-want-bijna-nie mand-begrijpt-hoe-het-werkt-a3983071.

37. M.J. Thurlings-Rassa, 'De $\mathrm{CO}_{2}$-taks en het ETS: een verkenning van mogelijke effecten', MenR 2019/50.

38. Art. $16.5 \mathrm{Wm}$ jo. art. $1 \mathrm{a}$ onder $1^{\circ} \mathrm{WED}$.

39. Art. $18.18 \mathrm{Wm}$ jo. art. $1 \mathrm{a}$ onder $1^{\circ} \mathrm{WED}$.

40. Art. $6.19 \mathrm{Wm}$ jo. art. $1 \mathrm{a}$ onder $1^{\circ} \mathrm{WED}$.

41. Art. $16.13 \mathrm{Wm}$ jo. art. $1 \mathrm{a}$ onder $1^{\circ} \mathrm{WED}$

42. Art. $16.37 \mathrm{Wm}$

43. Van een strafbaar feit kan wel sprake zijn indien de deelnemer een andere overtreding begaat, zoals een overtreding van vergunningvoorschriften (art. 16.5 Wm jo. art. 1 a onder $1^{\circ} \mathrm{WED}$ ). dient zijn overtreding wel ongedaan te maken door, kortgezegd, meer emissierechten bij te kopen. ${ }^{44}$ Daarnaast wordt een bestuurlijke boete opgelegd van $€ 100$ per te veel geëmitteerde ton $\mathrm{CO}_{2}$ en wordt de naam van de overtreder openbaar gemaakt. ${ }^{45}$ De boete is overigens een aanzienlijk bedrag vergeleken met de huidige prijs van een emissierecht van ongeveer $€ 25$.

In Nederland bestaat geen gepubliceerde strafrechtelijke jurisprudentie met betrekking tot gedragingen in strijd met hoofdstuk $16 \mathrm{Wm}$ door deelnemers aan het Europese emissiehandelssysteem. De Nederlandse Emissieautoriteit treedt wel bestuursrechtelijk handhavend op. Het betreft met name zaken waarin sprake was van fouten in de berekening en opgave van de hoeveelheid broeikasgasemissies. ${ }^{46}$ Volgens de wetsgeschiedenis dient strafrechtelijke handhaving te worden gezien als sluitstuk, waarbij uitgangspunt is dat overtredingen bestuursrechtelijk worden gehandhaafd. Indien sprake is van 'verzwarende omstandigheden' bij de overtreding, dan kan dit nopen tot inzet van het strafrecht. Dit houdt onder meer in dat fraude in beginsel altijd strafrechtelijk zal worden afgedaan. ${ }^{47}$

Er vinden daarentegen veel strafzaken plaats op het gebied van btw-carrouselfraude met emissierechten, waaronder in het Verenigd Koninkrijk, ${ }^{48}$ Frankrijk $^{49}$ en Duitsland. ${ }^{50}$ Het gaat dan niet om de regels die zich richten tot deelnemers aan het Europese emissiehandelssysteem, maar om fraude met emissierechten door derden. ${ }^{51}$ Verschillende instanties, waaronder Interpol ${ }^{52}$ en de Nederlandse Emissieautoriteit, ${ }^{53}$ waarschuwen al langer voor de fraudegevoeligheid van het Europese emissiehandelssysteem. Ook de Nederlandse strafrechtelijke jurisprudentie kent een voorbeeld van btw-carrouselfraude met emissierechten. De veroordeelde kocht

44. Art. $16.39 \mathrm{Wm}$.

45. Art. $18.16 \mathrm{a}$ en $18.16 \mathrm{p}$ Wm. De prijs van $€ 100$ wordt jaarlijks geïndexeerd in lijn met de Europese Richtlijn Emissiehandel.

46. Zie bijvoorbeeld rb. Den Haag 7 maart 2017, ECLI:NL:RBDHA: 2017:2421, ABRvS 8 augustus 2018, ECLI:NL:RVS:2018:2627 en Nederlandse Emissieautoriteit, NEa geeft onderneming een boete van $€$ 376.490,- voor monitorings- en rapportagefouten, 2 oktober 2019 , www.emissieautoriteit.nl/over-de-nea/documenten/publicatie/2019/ 10/02/bestuurlijke-boete-eh-2-10-2019.

47. Kamerstukken II 2003/04, 29565, nr. 3.

48. N. Huber, 'Fraudsters target tax on carbon credits', The Telegraph 19 juli 2009, www.telegraph.co.uk/finance/5866178/Fraudsters-targettax-on-carbon-credits.html.

49. M. Bosseli \& M. Szabo, 'Probe under way in alleged French $\mathrm{CO}_{2}$ VAT fraud', Reuters 11 juni 2009, www.reuters.com/article/us-franceprobe-co2/probe-under-way-in-alleged-french-co2-vat-fraud-idUSTRE 55A2EE20090611.

50. 'German court backs jail term for Deutsche banker's role in carbon tax fraud', Reuters 15 mei 2018, www.reuters.com/article/us-deutschebank-court/german-court-backs-jail-term-for-deutsche-bankers-role-incarbon-tax-fraud-idUSKCN1IG185.

51. De Deense documentaire Carbon Crooks uit 2014 geeft een goed beeld van fraude met het Europese emissiehandelssysteem.

52. Interpol, Guide to Carbon Trading Crime, juni 2013, globalinitiative.net/wp-content/uploads/2017/12/EUROPOL-Guide-to-CarbonTrading-Crime-2013.pdf.

53. Nederlandse Emissieautoriteit, Frauderisico's bij handel in emissierechten, 30 september 2010, zoek.officielebekendmakingen.nl/blg-93 750.pdf. 
in dat geval emissierechten in het buitenland en verkocht deze vervolgens door binnen een criminele organisatie. Die criminele organisatie verkocht die emissierechten door op de Nederlandse emissierechtenbeurs. Over de in het buitenland aangekochte emissierechten was geen btw verschuldigd. De criminele organisatie verkocht deze vervolgens in Nederland met btw. Het bedrag aan btw, van meer dan $€ 6$ miljoen, werd niet aan de Nederlandse fiscus afgedragen. Het gaat in dit geval om een veroordeling voor een fiscaal delict, het leidinggeven aan een criminele organisatie en valsheid in geschrift. ${ }^{54}$ Dit betreft dus geen veroordeling voor het overtreden van hoofdstuk $16 \mathrm{Wm}$.

\subsubsection{Emissietest voor voertuigen}

Auto's vormen een belangrijke bron van uitstoot van $\mathrm{CO}_{2}$. Op grond van het Europees recht is de fabrikant van een nieuw voertuigmodel verplicht te zorgen dat een voertuig het typegoedkeuringsproces heeft doorlopen, voordat deze mag worden verkocht binnen de Europese Unie. ${ }^{55}$ Als onderdeel van dit proces wordt getest hoeveel verontreinigende stoffen een voertuig uitstoot, waaronder de broeikasgassen $\mathrm{CO}_{2}$, methaan en stikstof. ${ }^{56}$

De verplichting om het typegoedkeuringsproces juist te doorlopen is in het Nederlands recht neergelegd in het Besluit typekeuring motorrijtuigen luchtverontreiniging, dat berust op de artikelen 9.5.1 en 9.5.6 Wm. ${ }^{57}$ Overtredingen van voorschriften, gesteld bij of krachtens deze artikelen, zijn strafbaar gesteld via de WED. ${ }^{58}$ Wij zijn niet bekend met strafrechtelijke procedures op grond van overtreding van het Besluit typekeuring motorrijtuigen luchtverontreiniging. ${ }^{59}$

De typegoedkeuringsregels kregen strafrechtelijke aandacht vanwege het 'emissieschandaal' dat in 2015 an het licht kwam. De kwestie kwam aan de orde toen Volkswagen, na onderzoek door de International Council on Clean Transportation, in de Verenigde Staten ervan werd verdacht zich niet te houden aan emissienormen. ${ }^{60}$ Centraal stond het verschil tussen de voertuigemissieniveaus in de testruimte enerzijds en de daadwerkelijke emissie van deze voertuigen op de weg anderzijds. De lagere emissieniveaus in de testruimte werden veroorzaakt door zogenoemde 'sjoemelsoftware'. Deze software herkende het als de auto werd getest in de testruimte. Door inschakeling van een emissiecontrolesysteem produceerde de auto dan minder emissies dan onder normale rijomstandigheden op de weg het geval

54. Rb. Den Haag 12 juni 2018, ECLI:NL:RBDHA:2018:6869.

55. Verordening (EG) $715 / 2007$

56. Verordening (EG) $443 / 2009$.

57. Zie bijvoorbeeld Stb. 2014, 120.

58. Art. $1 \mathrm{a}$ onder $2^{\circ}$ WED.

59. Opmerking verdient dat het Besluit typekeuring motorrijtuigen luchtverontreiniging wel wordt genoemd in een veroordeling voor overtreding van art. 72 Wegenverkeerswet 1994. Zie hof Leeuwarden 17 april 2003, ECLI:NL:GHLEE:2003:AF8424

60. United States Environmental Protection Agency, Volkswagen Violations, 10 maart 2020, www.epa.gov/vw/learn-about-volkswagenviolations. zou zijn. ${ }^{61}$ Deze kwestie leidde onder meer tot een boete voor Volkswagen van $€ 1$ miljard in Duitsland. ${ }^{62}$

\subsubsection{Energiebesparingsplicht voor bedrijven}

Een ander voorbeeld van wetgeving om $\mathrm{CO}_{2}$-uitstoot te reduceren is de wetgeving die bedrijven verplicht om investeringen te doen in energie-efficiëntie. De gedachte achter deze wetgeving is dat energie die niet nodig is, ook niet hoeft te worden opgewekt in $\mathrm{CO}_{2}$-uitstotende installaties, waardoor de uitstoot van $\mathrm{CO}_{2}$ wordt verminderd. Deze regels vinden hun oorsprong in de Europese richtlijn energie-efficiëntie en zijn in het Nederlandse recht geimplementeerd in het Activiteitenbesluit milieubeheer. ${ }^{63}$ Artikel 2.15 van dit besluit verplicht bepaalde bedrijven om alle energiebesparende maatregelen te realiseren met een terugverdientijd van vijf jaar of minder. ${ }^{64}$ Voorbeelden zijn investeringen in isolatie, dubbelglas of een zuinigere stookinstallatie. ${ }^{65}$ De overheid richt zich op dit moment primair op het bewustmaken van bedrijven van deze energiebesparingsplicht, omdat op het gebied van deze regels nog weinig bekendheid bestaat. $^{66}$ Bestuursrechtelijke handhaving komt echter op gang en richt zich op dit moment met name op de verplichting voor bedrijven om voor 1 juli 2019 te melden welke energiebesparende maatregelen zij hebben genomen. ${ }^{67}$ Overtreding van deze verplichting is tevens een economisch delict, maar wij zijn vooralsnog niet bekend met daadwerkelijke strafvervolgingen. ${ }^{68}$ De Europese Commissie stuurt aan op strenge handhaving van deze regelgeving. ${ }^{69}$

61. European Court of Auditors, The EU's response to the dieselgate scandal, februari 2019, www.eca.europa.eu/lists/ecadocuments/ brp_vehicle_emissions/brp_vehicle_emissions_en.pdf.

62. B. van de Weijer, 'Volkswagen krijgt boete van 1 miljard euro in Duitsland voor dieselfraude', De Volkskrant 13 juni 2018, www.volkskrant.nl/nieuws-achtergrond/volkswagen-krijgt-boete-van1-miljard-euro-in-duitsland-voor-dieselfraude bc30134b/.

63. Richtlijn (EU) $27 / 2012$.

64. Deze verplichting richt zich ingevolge art. 2.14c Activiteitenbesluit milieubeheer tot ieder rechtssubject die een inrichting type $A$ of een inrichting type B drijft. Voor toepassing geldt ingevolge art. 2.15 lid 7 Activiteitenbesluit milieubeheer een minimumdrempelwaarde van een energieverbruik van $50.000 \mathrm{kWh}$ elektriciteit of $25.000 \mathrm{~m} 3$ aardgas(equivalent) of meer per kalenderjaar. Voor een bestuursrechtelijke uitspraak op het gebied van de verplichting uit art. 2.15 Activiteitenbesluit milieubeheer, zie ABRvS 23 mei 2018, ECLI:NL:RVS:2018:1688, NJB $2018 / 1157$. Ook voor andere instellingen bestaan energiebesparingsplichten, maar het gaat buiten de reikwijdte van dit artikel om daar een volledige uiteenzetting van te geven.

65. Bijlage 10 Activiteitenregeling milieubeheer bevat erkende maatregelen voor energiebesparing in het licht van de verplichting uit art. 2.15 Activiteitenregeling milieubeheer.

66. Brief van de Minister van Economische Zaken en Klimaat van 8 november 2019, DGKE-WO/19238071.

67. Rijksoverheid. Nieuwsbericht, Ruim 22.000 rapportages Informatieplicht ingediend, 2 juli 2019, www.rijksoverheid.nl/actueel/nieuws/ 2019/07/02/ruim-22.000-rapportages-informatieplicht-ingediend.

68. Het activiteitenbesluit is gebaseerd op art. 8.40 lid $1 \mathrm{Wm}$. Overtredingen van voorschriften gesteld bij of krachtens dat artikel zijn strafbaar gesteld in art. $1 \mathrm{a}$ onder $1^{\circ}$ WED.

69. Commissiedocument 640 van 2019. 


\subsubsection{Regels met betrekking tot de uitstoot van andere broeikasgassen: methaan en F-gassen}

Methaan is na $\mathrm{CO}_{2}$ het broeikasgas dat het meeste bijdraagt aan het broeikaseffect, veroorzaakt door de mens. Bij tal van productieprocessen, zoals in de veehouderij en bij de winning van aardgas, komt methaan vrij. Allerlei regels beperken de uitstoot van methaan. Voor het winnen van aardgas op land heeft een mijnbouwonderneming bijvoorbeeld een omgevingsvergunning nodig, waarin beperkingen worden gesteld aan de emissie van methaan. Ook vergunningen voor bijvoorbeeld stortplaatsen bevatten veelal regels omtrent uitstoot, monitoring en afvang van methaan. Overtreding van voorschriften van omgevingsvergunningen zijn - in algemene zin - strafbaar via de WED. ${ }^{70}$ Dergelijke overtredingen leiden ook daadwerkelijk tot strafvervolgingen. ${ }^{71}$

Andere broeikasgassen zijn de gefluoreerde broeikasgassen (HFK's, PFK's, SF6), ook wel bekend als de F-gassen. In de Europese Unie geldt de F-gassenverordening, die in Nederland is geimplementeerd in het Besluit gefluoreerde broeikasgassen en ozonlaag afbrekende stoffen. ${ }^{72}$ Kortgezegd moeten producten die F-gassen bevatten geleidelijk worden uitgefaseerd, en mogen sommige F-gassen inmiddels al niet meer worden gebruikt. ${ }^{73}$ In de praktijk betekent dat bijvoorbeeld dat schadelijke koelvloeistoffen niet mogen worden bijgevuld en dat bedrijven investeringen moeten doen in onder meer nieuwe koelinstallaties. Voor bijvoorbeeld een vleesverwerkingsbedrijf of datacentrum kan dat aanzienlijke kosten met zich brengen. Overtreding van het Besluit gefluoreerde broeikasgassen en ozonlaag afbrekende stoffen is een economisch delict in de zin van de WED. ${ }^{74}$ Met strafrechtelijke veroordelingen wegens het overtreden van F-gassenwetgeving zijn wij evenwel niet bekend. Bestuursrechtelijke handhaving vindt wel plaats, hoewel slechts beperkt jurisprudentie op dit gebied te vinden is. ${ }^{75}$

\subsection{Sancties en opzet in de WED}

Wij hebben in de voorgaande paragrafen enkele klimaatnormen besproken waarvan overtreding strafbaar is gesteld in de WED. De hoogte van de maximale boete en gevangenisstraf voor overtredingen van normen in de WED is ten eerste afhankelijk van de overtreden

70. Art. $18.18 \mathrm{Wm}$ jo. art. $1 \mathrm{a}$ onder $1^{\circ} \mathrm{WED}$.

71. Zie bijvoorbeeld HR 22 juni 2010, ECLI:NL:HR:2010:BK3526, NJ 2010/476.

72. Verordening (EU) $517 / 2014$.

73. Op grond van art. 4 Besluit gefluoreerde broeikasgassen en ozonlaag afbrekende stoffen is per 1 januari 2015 bijvoorbeeld het bijvullen van R22-koudemiddelen niet meer toegestaan. Op dit moment wordt op Europees niveau gewerkt aan een herziening van de F-gassenverordening waarbij een aanzienlijke verdere vermindering van de emissies van F-gassen wordt beoogd.

74. De rechtsbasis van genoemde algemene maatregelen van bestuur staat in art. 1 onder $1^{\circ}$ WED. Dit artikel verwijst voor de strafbaarstelling naar voorschriften die bij of krachtens algemene maatregel als bedoeld in art. 9.2.2.1 Wm zijn gesteld.

75. Zie bijvoorbeeld ABRvS 25 april 2018, ECLI:NL:RVS:2018:1393. norm. ${ }^{76}$ Als een overtreding opzettelijk is begaan, kan een zwaardere sanctie worden opgelegd. ${ }^{77}$ Voor opzet in de WED is boos opzet niet vereist. Boos opzet houdt in dat 'de dader opzet had, niet alleen op zijn gedraging en de andere relevante bestanddelen van de delictsomschrijving, maar tevens op de omstandigheid dat zijn gedraging strijdt met het geldende recht' ${ }^{78}$ De WED kent evenwel een kleurloos opzetvereiste. Dit houdt in dat het opzet louter moet zien op de kernbestanddelen van de gedraging zoals die ligt besloten in de delictsomschrijving, en niet op het (daarmee) overtreden van de norm. Het gaat er - kort gezegd - dus om of een partij de regels overtreedt; niet of die partij weet dat hij de regels overtreedt. Een partij kan zich in dat kader dus niet verschuilen achter onwetendheid ten aanzien van klimaatregelgeving. ${ }^{79}$ De onbekendheid met het feit dat een vergunning nodig is voor het exploiteren van een broeikasgasinstallatie, levert bijvoorbeeld geen gegrond verweer op.

\subsection{Bestuursrechtelijke of strafrechtelijke handhaving}

Wij bespraken al een aantal keer dat klimaatwetgeving zowel bestuurs- als strafrechtelijk kan worden gehandhaafd. Hall verdedigt een systeem dat klimaatregelgeving zowel bestuursrechtelijk als strafrechtelijk handhaaft:

'Whilst criminal sanctions may seem desirable in terms of their associated moral censure and (arguable) deterrence and preventative attributes, the application of criminal law to climate change is conceptually and pragmatically challenging in terms of achieving actual convictions. This is true both in relation to domestic criminal justice systems (especially given the high threshold of proof and causation required in these cases) and for the application of international criminal law in such cases. As such, a combined approach encompassing criminal and administrative sanctions may be more workable. ${ }^{, 80}$

Vanwege het una via-beginsel bestaat beperking ten aanzien van het zowel bestuursrechtelijk als strafrechtelijk handhaven voor dezelfde feiten. ${ }^{81}$ Als uitgangspunt geldt dat het strafrecht alleen als ultimum

76. Art. 6 lid 1 WED.

77. Art. 6 lid 1 jo. art. 2 lid 1 WED.

78. F. de Jong \& E. Sikkema, 'Subjectieve bestanddelen', in: F.G.H. Kristen e.a. (red.), Bijzonder strafrecht: Strafrechtelijke handhaving van sociaal-economisch en fiscaal recht in Nederland, Den Haag: Boom juridisch 2019, p. 489-491.

79. Voor meer informatie over opzet in het bijzonder strafrecht, zie F. de Jong \& E. Sikkema, 'Subjectieve bestanddelen' in: F.G.H. Kristen e.a. (red.), Bijzonder strafrecht: Strafrechtelijke handhaving van sociaaleconomisch en fiscaal recht in Nederland, Den Haag: Boom juridisch 2019, p. 485-522

80. M. Hall, 'Criminal law and climate change', in: M. Faure (red.), Elgar Encyclopedia of Environmental Law, Cheltenham: Edward Elgar Publishing 2016, p. 103

81. Art. 5:44 Awb en art. 243 lid 2 Sv. Zie ook J.H. Crijns, 'Vervolging en berechting' in: F.G.H. Kristen e.a. (red.), Bijzonder strafrecht: Strafrechtelijke handhaving van sociaal-economisch en fiscaal recht in Nederland, Den Haag: Boom juridisch 2019, p. 636-640. 
remedium wordt aangewend. ${ }^{82}$ In de praktijk hangt de keuze voor bestuursrecht of strafrecht af van verschillende factoren, waaronder met name of sprake is van een besloten of open context. ${ }^{83}$ Andere relevante factoren zijn de aard en ernst van de overtreding en of een vrijheidsstraf wenselijk wordt bevonden. ${ }^{84}$ Beleid omtrent keuzes voor bestuursrechtelijke of strafrechtelijke handhaving ligt grotendeels vast in convenanten, handhavingsarrangementen en beleidsregels. ${ }^{85}$

Het Openbaar Ministerie zal in ernstige zaken eerder opsporingscapaciteit inzetten, zo volgt ook uit de Aanwijzing voor de opsporing ${ }^{86}$ en de Landelijke handhavingstrategie. ${ }^{87}$ Het is aannemelijk dat overtredingen van klimaatregelgeving als ernstiger worden beoordeeld naarmate de gevolgen van klimaatverandering merkbaarder worden en het ingrijpen in de uitstoot van broeikasgassen urgenter wordt. Het is daarom voorstelbaar dat in de toekomst vaker voor strafrechtelijke handhaving zal worden gekozen.

\section{Toekomstige klimaatwetgeving}

In de komende jaren zullen we veel nieuwe klimaatregelgeving zien; ten eerste omdat de stand van klimaatverandering spoedige en ingrijpende maatregelen vereist. Nederland moet daarnaast nog veel doen om haar klimaatdoelen te bereiken, zoals wij in onze introductie bespraken. Wij zien ook de vraag om dergelijke regelgeving sterk toenemen; niet alleen bij burgers, zoals bleek uit verschillende recente grote klimaatprotesten

82. Voor een achtergrond en nuancering van dit uitgangspunt, zie J.H. Crijns, 'Strafrecht als ultimum remedium: Levend leidmotief of archaïsch desideratum?', AA 2012(12), p. 11-18.

83. 'Bij een besloten context is er sprake van (1) een gespecialiseerd bestuursorgaan dat met de uitvoering van bepaalde wetten is belast, en uit dien hoofde te maken heeft met een afgebakende doelgroep; alsmede van (2) verbindingen (en vaak ook communicatie) tussen dat orgaan en de doelgroep ter uitvoering van de wet of ten behoeve van het toezicht op de naleving van die wet.' Zie J.H. Crijns 'Op zoek naar consistentie Bestraffing buiten de rechter om in strafrecht en bestuursrecht', Rechtsgeleerd Magaziin Themis 2014/5, p. 271.

84. B. van der Vorm, 'De keuze tussen strafrechtelijke en bestuursrechtelijke sanctionering en het criterium van de ernstige gedraging', PROCES 96(4) 2017, p. 267-280 en J.H. Crijns, 'Vervolging en berechting' in: F.G.H. Kristen e.a. (red.), Bijzonder strafrecht: Strafrechtelijke handhaving van sociaal-economisch en fiscaal recht in Nederland, Den Haag: Boom juridisch 2019, p. 625-628.

85. Zie bijvoorbeeld Convenant ter voorkoming van ongeoorloofde samenloop van bestuurlijke en strafrechtelijke sancties (Stcrt. 2009, 665) en Protocol aanmelding en afdoening van fiscale delicten en delicten op het gebied van douane en toeslagen (Stcrt. 2015, 17271). Zie ook J.H. Crijns, 'Vervolging en berechting' in: F.G.H. Kristen e.a. (red.), Bijzonder strafrecht: Strafrechtelijke handhaving van sociaal-economisch en fiscaal recht in Nederland, Den Haag: Boom juridisch 2019, p. 614-617.

86. Aanwijzing voor de opsporing (2013A020) in werking getreden op 1 januari 2014.

87. Landelijke handhavingstrategie van 24 april 2014. wereldwijd, maar ook bij een deel van het bedrijfsleven. ${ }^{88}$

Binnen de Nederlandse politiek en strafrechtswetenschap wordt nog betrekkelijk weinig debat over de rol van het strafrecht bij de aanpak van klimaatverandering als zodanig gevoerd, maar er zijn inmiddels wel verschillende voorstellen voor klimaatwetgeving waarvan te verwachten is dat deze (mede) strafrechtelijk kunnen worden gehandhaafd. Wij bespreken hier enkele van deze voorstellen.

De komende jaren zullen we naar verwachting meer belastingwetgeving zien die dient ter bestrijding van klimaatverandering. De meest in het oog springende maatregel op dit gebied is de invoering van een $\mathrm{CO}_{2^{-}}$ belasting. De Tweede Kamer heeft in dit kader de Wet minimum $\mathrm{CO}_{2}$-prijs elektriciteitsopwekking in behandeling. ${ }^{89}$ Dit wetsvoorstel heeft als doel om ondernemingen, die vallen binnen de reikwijdte van het Europese emissiehandelssysteem, een aanvullende $\mathrm{CO}_{2^{-}}$ belasting te laten betalen indien de $\mathrm{CO}_{2}$-prijs binnen het Europese emissiehandelssysteem lager is dan een nationale minimumprijs. Ook andere voorstellen voor fiscale klimaatwetgeving worden besproken. Zo heeft de Tweede Kamer een voorstel voor de Wet vliegbelasting in behandeling. Deze wet beoogt een heffing op vervuilende vliegtuigen en een belasting per vliegtuigpassagier. ${ }^{90}$ Tot slot noemen wij hier het Europese fiscale voorstel van een 'Carbon Border Tax'. Dit is een heffing op de invoer van bepaalde producten van buiten de Europese Unie om de uitstoot van $\mathrm{CO}_{2}$ te belasten die bij de productie daarvan vrijkwam. Met deze belastingwet beoogt de Europese Unie oneerlijke bevoordeling tegen te gaan van landen buiten de Europese Unie die minder aan $\mathrm{CO}_{2}$-reductie doen. ${ }^{91}$ Overtredingen van fiscale wetgeving kunnen onder omstandigheden tot strafrechtelijke aansprakelijkheid leiden. Zo stelt artikel 68 lid 1 Algemene wet inzake rijksbelastingen bepaalde gedragingen met betrekking tot belastingwetgeving strafbaar, waaronder het niet, onjuist of onvolledig verstrekken van gegevens, het in valse vorm beschikbaar stellen van bescheiden en het uitreiken van een onjuiste factuur. ${ }^{92}$

Wij verwachten in de komende jaren ook een toename van financiële regelgeving die beoogt klimaatverandering tegen te gaan. De Serrière zet in een artikel uit 2020 uiteen welke financiële regelgeving kan worden

88. Zie bijvoorbeeld M. Kerres, 'In Davos zijn de meesten voor het klimaat - zeggen ze', NRC Handelsblad 25 januari 2020

89. Kamerstukken I/ 2018/19, 35216, nr. 2

90. Kamerstukken // 2018/19, 35205, nr. 2

91. F. Guarascio \& J. Ekblom, 'Explainer: What an EU carbon border tax might look like and who would be hit', Reuters 10 december 2019 www.reuters.com/article/us-climate-change-eu-carbontax-explainer/ explainer-what-an-eu-carbon-border-tax-might-look-like-and-whowould-be-hit-idUSKBN1YE1C4.

92. Voor een overzicht met betrekking tot het strafrechtelijk handhaven van fiscale regelgeving, zie E.C.A. Bakker, 'Fiscale delicten', in: F.G.H. Kristen e.a. (red.), Bijzonder strafrecht: Strafrechtelijke handhaving van sociaal-economisch en fiscaal recht in Nederland, Den Haag: Boom juridisch 2019, p. 279-313. 
aangewend om aan financiële instellingen voor te schrijven een bijdrage te leveren om klimaatdoelstellingen te halen. ${ }^{93}$ Hij bespreekt onder meer mogelijke regelgeving, waarbij financiële instellingen een hogere margin moeten rekenen voor klanten die bijdragen aan klimaatverandering. Dit zou kunnen betekenen dat banken een hogere rente op leningen moeten rekenen voor klanten in sectoren die veel $\mathrm{CO}_{2}$ uitstoten. Hij bespreekt daarnaast mogelijke regelgeving met betrekking tot juridische vereisten waaraan financiële producten moeten voldoen om als 'groen' of 'duurzaam' te kwalificeren. Overtredingen van dergelijke regelgeving kunnen in de WED strafbaar worden gesteld, zoals ook is gedaan voor andere financiële regelgeving. ${ }^{94}$

Een wat minder concreet voorbeeld is wetgeving ter inkrimping van de veestapel. De Raad voor Leefomgeving en Infrastructuur adviseerde al in 2018 dat een forse krimp van de veestapel nodig is om de klimaatdoelen van Parijs te halen. ${ }^{95}$ D66 stelde, naar aanleiding van de stikstofcrisis, ook een drastische inkrimping van de veestapel voor. ${ }^{96}$ Via de WED kunnen bijvoorbeeld regels over maximumaantallen vee per boer mogelijk strafrechtelijk worden gehandhaafd. De administratie van hoeveelheden vee krijgt vanaf 2018 al strafrechtelijke aandacht door de zogenaamde 'kalverenfraude'. ${ }^{97}$

Het is aldus onvermijdelijk dat veel nieuwe klimaatwetgeving op komst is, maar het is moeilijk te voorspellen om pat voor wetgeving het zal gaan. Klimaatjournalist Jelmer Mommers schrijft 'dat een totale vernieuwing van alle sectoren van de economie nodig is: infrastructuur, vervoer, woningen, energieopwekking, voedsel en de industrie' ${ }^{98}$ Het is op veel van die gebieden nog onduidelijk hoe die vernieuwing er precies zal uitzien en welke wetgeving daarbij zal horen. Ook is de vraag of, en in hoeverre zal worden gekozen voor handhaving langs de weg van het strafrecht. Door de gespecialiseerde aard van bepaalde klimaatwetgeving, is het voorstel-

93. V.P.G. de Serrière, 'Toekomstmuziek of utopie: kan de overheid voorschrijven dat de financiële sector meer substantieel bijdraagt aan het bereiken van klimaatdoelstellingen? Een overzicht', Ondernemingsrecht 2020/12, p. 53-66.

94. Zie bijvoorbeeld de strafbaarstelling van overtredingen van artikelen uit de Wet op het financieel toezicht in art. 1 onder $2^{\circ}$ WED.

95. P. Hotse Smit, 'Nederlandse veestapel moet fors krimpen om klimaatdoelen Parijs te halen, adviseert Raad. En snel ook', De Volkskrant 3 april 2018, www.volkskrant.nl/nieuws-achtergrond/nederlandseveestapel-moet-fors-krimpen-om-klimaatdoelen-parijs-te-halen-ad viseert-raad-en-snel-ook b239ec79.

96. D. Mebius, 'D66 doet eerste zet in stikstofdossier: halvering veestapel moet bouw mogelijk maken', De Volkskrant 9 september 2019, www.volkskrant.nl/nieuws-achtergrond/d66-doet-eerste-zet-in-stikstof dossier-halvering-veestapel-moet-bouw-mogelijk-maken b0501ed8/.

97. Zie bijvoorbeeld D. Mebius, 'Ruim 2.100 veeboeren maakten zich in 2017 schuldig aan kalverfraude. Wat zijn de gevolgen? Vijf vragen', De Volkskrant 8 februari 2018, www.volkskrant.nl/economie/ruim-2-100veeboeren-maakten-zich-in-2017-schuldig-aan-kalverfraude-wat-zijnde-gevolgen-vijf-vragen bea0e1bf/.

98. J. Mommers, 'Klimaat en energie spelen een hoofdrol in de formatie. Dit zijn de strijdpunten', De Correspondent 24 maart 2017, decorrespondent.nl/6452/klimaat-en-energie-spelen-een-hoofdrol-in-de-formatie-dit-zijn-de-strijdpunten/711068468-b2e863e7. baar dat gespecialiseerde bestuursrechtelijke organen, zoals de Nederlandse Emissieautoriteit, beter kunnen onderzoeken en handhaven dan het Openbaar Ministerie. Anderzijds rechtvaardigen de gevolgen die klimaatverandering teweeg kan brengen de inzet van het strafrecht.

\section{Conclusie}

Het bijdragen aan klimaatverandering is als zodanig niet strafbaar, omdat dit onverenigbaar is met de strafrechtelijke regels ten aanzien van causaliteit en legaliteit. Internationaal vinden echter wel strafrechtelijke onderzoeken plaats naar het onjuist of onvolledig informeren van investeerders over klimaatverandering. Dit soort onderzoeken zijn ook in Nederland denkbaar. De Nederlandse wet kent daarnaast allerlei klimaatnormen waarvan overtreding strafbaar is gesteld via de WED. Voorbeelden van dergelijke normen zijn de regels rondom het Europese emissiehandelssysteem, regels over energiezuinigheid voor bedrijven en over broeikasgasemissies door auto's.

Wij verwachten dat klimaatverandering een grotere rol binnen het strafrecht gaat spelen. Ten eerste is het onvermijdelijk dat de hoeveelheid klimaatregels zal toenemen, en is het zeer waarschijnlijk dat een aanzienlijk gedeelte van deze regels strafrechtelijk kan worden gehandhaafd. Het zou dan kunnen gaan om bijvoorbeeld wetgeving voor een inperking van de veestapel, de invoering van een $\mathrm{CO}_{2}$-belasting en regels voor financiële ondernemingen. Ten tweede is het aannemelijk dat in de toekomst bij overtredingen van klimaatwetgeving vaker voor strafrechtelijke handhaving boven bestuursrechtelijke handhaving zal worden gekozen. De Staat weet door het Urgenda-arrest dat bepaalde klimaatdoelen juridisch afdwingbaar zijn. Om deze klimaatdoelen te halen, is de Staat deels afhankelijk van de mate waarin klimaatregelgeving wordt nageleefd. De afschrikwekkende werking van het strafrecht kan daarbij in bepaalde gevallen helpen. Daarnaast is een belangrijk oriëntatiepunt bij de keuze tussen strafrechtelijke en bestuursrechtelijke handhaving of de overtreding ernstig is. Overtredingen van klimaatwetgeving zullen waarschijnlijk als ernstiger worden ervaren, naarmate de gevolgen van klimaatverandering merkbaarder worden en het ingrijpen in de uitstoot van broeikasgassen urgenter wordt. Gezien de stand en ontwikkeling van het klimaat en van de wereldwijde broeikasgasuitstoot is het goed denkbaar dat dit scenario zich zal voordoen.

Een belangrijk deel van de te verwachten handhaving op het gebied van klimaatregelgeving zal zich echter binnen de kaders van het bestuursrecht afspelen. Klimaatnormen richten zich veelal tot specifieke rechtssubjecten binnen een besloten context, zoals bij het Europees emissiehandelssysteem. In dergelijke gevallen vindt vaker bestuursrechtelijke handhaving plaats. Daarnaast vraagt de specialistische aard van veel klimaatregelge- 
ving om onderzoek door gespecialiseerde bestuursrechtelijke organen, zoals omgevingsdiensten en de Nederlandse Emissieautoriteit. 